

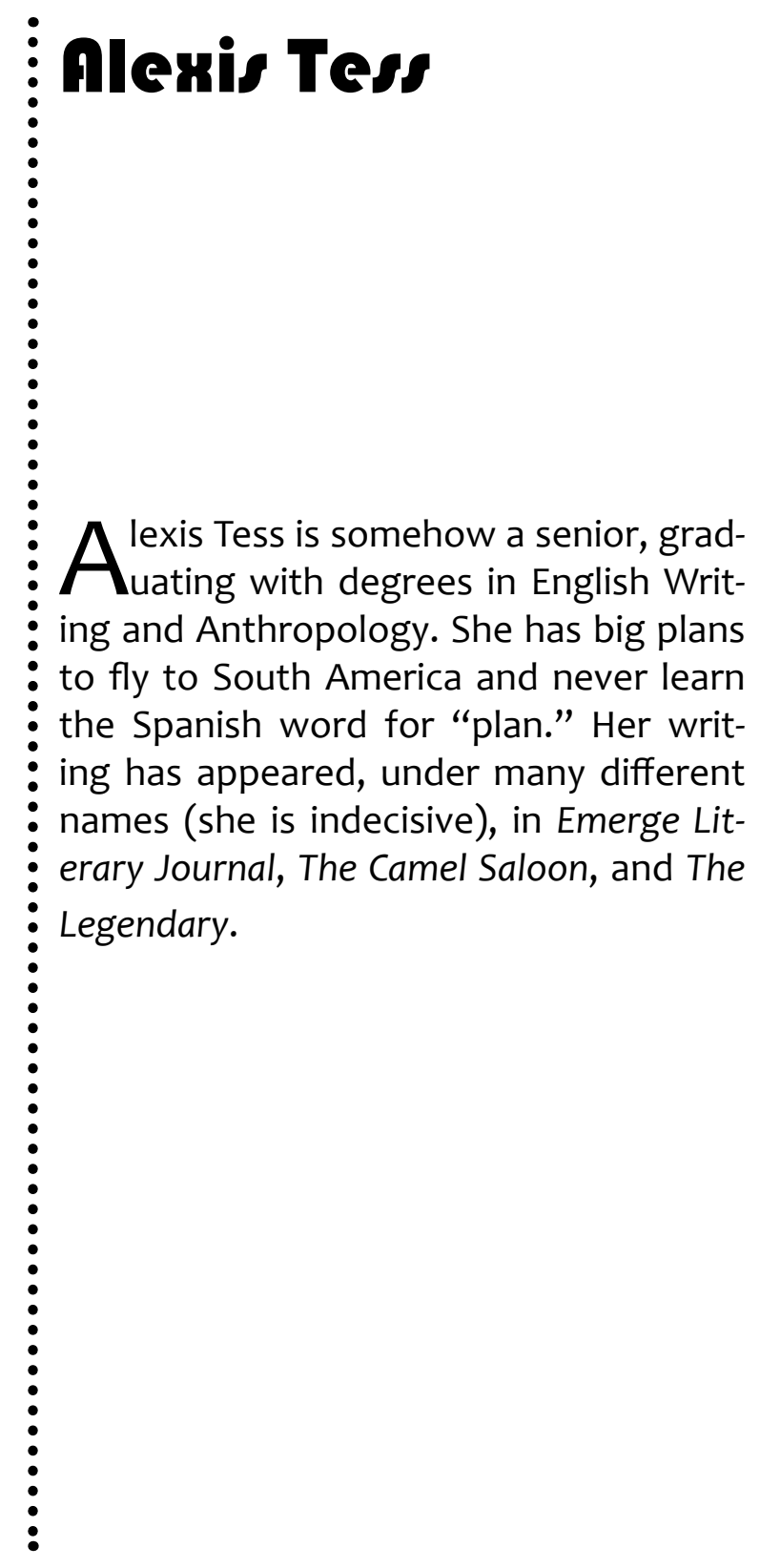


FORBES \& FIFTH

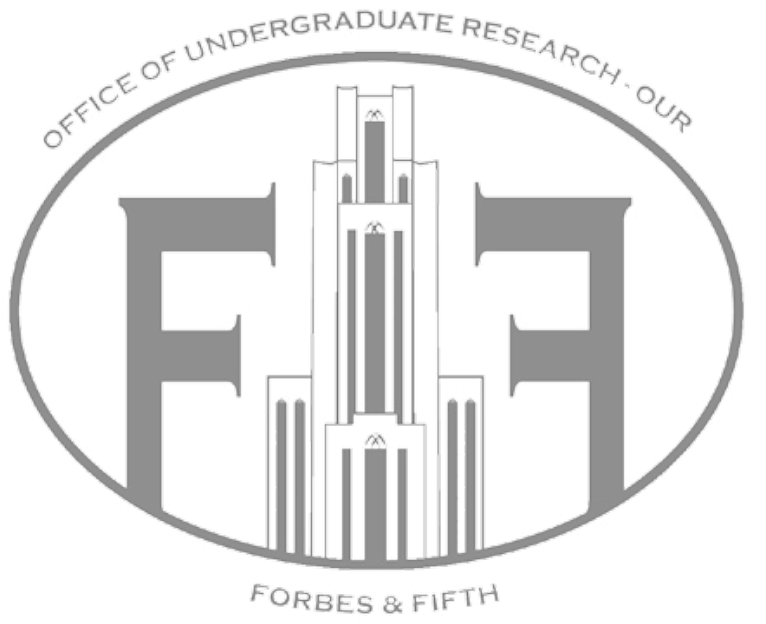




\section{When the Falling is Done}

It's like...

(search the skies)

it's like

finding the most wonderful chocolate bar. It's the raspberry ooze at the heart of the truffle, it's the Willy Wonka Golden Ticket to romance, baby, one way.

Eyes smile at the sight, nostrils sigh at the scent, every muscle fiber shouts hallelujah!

and tap-dances in place.

So clutch the bar close to your chest, know it might melt one day, but that day is not today. For now

let it be

your savored, secret (almond) joy.

As soon as you're alone together, take a bite. A tiny one!

Don't ruin your appetite and

no! It's too good, take it all at once, shove

it in, swallow hard, let it

catch in your throat, let it

coat your vocal chords with sweetness.

You want it now?

You got it now. 
But wait, stop and save the last bite wrap it up in silver foil and tuck it away.

$* \quad * \quad *$

The days pass. And slowly, the sweetness is forgotten. Slowly, the Hershey Kiss compliments stop raining down. Chocolate droplets turn hard, hail, balled up wrappers pelt bare skin. Small, but man, do they sting.

And one day, you realize you can't move, you're buried beneath a mountain of waste.

Who knew whispers in the night had such weight?

Who else could love you? I mean, Who else could love you? I mean, Who else could-could-could-couldSTOP!

Too long you've said nothing, too long you've swallowed tough love, choked down your voice, put permanent teeth marks into your lips. Just. Stop.

Find the last bit of that wonderful chocolate bar. It's still in your pocket. 
Dig for it now, dig 'til fingernails pull back from flesh, 'til your heart pounds behind your eyes, 'til your stomach snarls in its den, and the weight of the world takes your breath away ahhhh

You find your chocolate and bring it to your lips just to taste the bitter bite of cocoa, a kiss of sawdust dried up on your tongue.

That is when you leave. That is when the falling is done. 